OPEN ACCESS

Edited by:

Asya Agulnik,

St. Jude Children's Research Hospital,

United States

Reviewed by:

Julie Fitzgerald,

Children's Hospital of Philadelphia,

United States

Christopher Dandoy,

Cincinnati Children's Hospital Medical

Center, United States

Matt S. Zinter,

University of California, San Francisco,

United States

*Correspondence:

Margaret L. MacMillan

macmi002@umn.edu

Specialty section:

This article was submitted to

Pediatric Critical Care

a section of the journal

Frontiers in Pediatrics

Received: 27 November 2020

Accepted: 01 July 2021

Published: 27 July 2021

Citation:

Ferdjallah A, Young J-AH and MacMillan ML (2021) A Review of

Infections After Hematopoietic Cell Transplantation Requiring PICU Care:

Transplant Timeline Is Key.

Front. Pediatr. 9:634449

doi: 10.3389/fped.2021.634449

\section{A Review of Infections After Hematopoietic Cell Transplantation Requiring PICU Care: Transplant Timeline Is Key}

\author{
Asmaa Ferdjallah ${ }^{1}$, Jo-Anne H. Young ${ }^{2}$ and Margaret L. MacMillan ${ }^{1 *}$ \\ ${ }^{1}$ Department of Pediatrics, Division of Blood and Marrow Transplantation and Cellular Therapy, University of Minnesota, \\ Minneapolis, MN, United States, ${ }^{2}$ Department of Medicine, Division of Infectious Disease and International Medicine, \\ Program in Transplant Infectious Disease, University of Minnesota, Minneapolis, MN, United States
}

Despite major advances in antimicrobial prophylaxis and therapy, opportunistic infections remain a major cause of morbidity and mortality after pediatric hematopoietic cell transplant $(\mathrm{HCT})$. Risk factors associated with the development of opportunistic infections include the patient's underlying disease, previous infection history, co-morbidities, source of the donor graft, preparative therapy prior to the graft infusion, immunosuppressive agents, early and late toxicities after transplant, and graft-vs.-host disease (GVHD). Additionally, the risk for and type of infection changes throughout the HCT course and is greatly influenced by the degree and duration of immunosuppression of the HCT recipient. Hematopoietic cell transplant recipients are at high risk for rapid clinical decompensation from infections. The pediatric intensivist must remain abreast of the status of the timeline from HCT to understand the risk for different infections. This review will serve to highlight the infection risks over the year-long course of the HCT process and to provide key clinical considerations for the pediatric intensivist by presenting a series of hypothetical HCT cases.

Keywords: hematopoietic stem cell transplantation, pediatric, immunosuppressed, sepsis, opportunistic infection

\section{INTRODUCTION}

Hematopoietic cell transplant (HCT) is a potential cure for many malignant and non-malignant diseases (1). As the indications for HCT broaden to include many genetic and inherited metabolic disorders, and the use of other cellular therapies increases, pediatric patients will undergo HCT at increasing volumes $(2,3)$.

In the pediatric intensive care unit (PICU), sepsis and infectious complications are common causes for admission after HCT (4). In a University of California study of 1,782 pediatric HCT patients admitted to the PICU, infection was documented in $45.7 \%$ of admissions, with $22.2 \%$ mortality (5). Hematopoietic cell transplant recipients were found to more likely present in septic shock and/or with respiratory failure than non-HCT PICU patients. Infections remain the leading immediate cause of mortality in HCT patients in the PICU (5). An Italian study of 496 children admitted to the PICU following HCT reported a mortality rate of $30-40 \%$ (6).

Hematopoietic cell transplant patients are at extraordinarily high risk for opportunistic infections for at least a year after transplant depending on several factors including underlying disease, donor graft source, and conditioning regimen among others; these factors 
will be discussed in further detail throughout this article (710). The risk for specific infections greatly varies during this timeline and depends upon several factors, particularly the state of the patient's immune system, which will not return to normal for at least a year after HCT (7). It is important to have a keen understanding of the various stages of HCT, associated risk factors for infections, and the state of the immune system throughout the HCT timeline, to successfully treat opportunistic infections in HCT patients.

\section{HEMATOPOIETIC CELL TRANSPLANT}

The goal of a HCT is to eliminate a patient's native bone marrow (BM) cells and to replace them with healthy donor cells (11). These native stem cells may contain a genetic mutation that is driving a certain disease state, or may be defective resulting in $\mathrm{BM}$ failure, or a neoplasm that cannot be destroyed with conventional chemotherapy or radiation (11). To destroy these errant stem cells, high dose chemotherapy and often radiation, are administered to ablate the BM to make space for new stem cells to begin the process of renewed hematopoiesis (12). With malignant diseases, chemotherapy and radiation, "the preparative regimen," also serves the purpose of killing any remaining residual cancer cells that may be present in the BM $(13,14)$. Donor cells are taken from the BM, which is the origin of stem cell production and differentiation, and this process is also referred to as a bone marrow transplant (BMT) (15). Alternatively, donor cells can be mobilized by administering medications to the donor and subsequently collecting the stem cells from the peripheral blood (a peripheral blood stem cell transplantation) (16). Donor stem cells are considered allogeneic, meaning they originate from another individual and not the patient (17). It is important to understand that the very nature of an allogenic transplant necessitates the use of immunosuppression for a short time to allow for the immunologic establishment of the new stem cells (17). For some conditions, the cure can be achieved with high dose chemotherapy followed by the infusion of a patient's own, previously collected, stem cells (11). This is termed an autologous HCT (11).

While relapsed, recurrent, and high-risk malignancies are the most common indications for HCT, the expanding list of conditions treated by HCT is diverse (18). Other indications for HCT include hemoglobinopathies, immune dysregulation, or deficiencies, BM failure syndromes, and inherited congenital metabolic disorders $(18,19)$. Some of these patients, such as those with BM failure syndromes or inherited congenital syndromes, will not have experienced extensive treatment for their disease before transplant (18). However, others, particularly those with certain types of aplastic anemia and malignancy, will have been heavily treated with chemotherapeutic agents and/or immunosuppressive drugs even prior to transplant (20). This is especially the case for patients with acute leukemia who may have received multiple courses of profoundly immunosuppressive therapy before transplant to achieve remission (21). Bone marrow failure patients may have spent weeks to years with varying states of neutropenia and so their period of high-risk status is longer than other patients (22). Additionally, patients with prolonged neutropenia may have had previously treated opportunistic infections prior to HCT (23). Providers should note the individual degree of neutropenia before HCT while caring for these patients for context when choosing diagnostic tests and empiric treatment agents for infections after HCT (23).

\section{PREPARATIVE REGIMEN}

The preparative regimen is typically administered for $5-7$ days prior to the transplant day (referred to as Day 0), depending on the underlying disease state (24). It includes high-dose chemotherapy with or without radiation (12). Immunosuppression is also started a few days prior to transplant for allogeneic HCT to allow for therapeutic drug serum levels as new stem cells establish themselves (25). During this early critical period, immunosuppression is key to prevent donor $\mathrm{T}$ lymphocytes from recognizing recipient cell antigens as foreign and attacking various organ systems (26). It must be noted however that although this immunosuppression is necessary, it contributes to delayed immune recovery following HCT (25).

Although anemia, lymphopenia, neutropenia, and thrombocytopenia usually become more severe as the transplant day nears and the cumulative effects of the preparative regimen are manifested, the patient's blood counts may not necessarily drop to zero by transplant day $(27,28)$. Despite this fact, this period places patients at high risk for spontaneous infection as these residual neutrophils do not function properly because of profound immune suppression (29). Existing portals of entry such as mucosal breakdown from mucositis and skin breaches from the presence of a central venous access line are risk factors for infection (29).

The preparative characteristic that is most predictive of risk of infection is its intensity which dictates the severity of tissue damage including mucositis and the duration of pancytopenia that follows (12). Patients receive various degrees of marrow ablating chemotherapy as determined by their underlying disease and comorbidities (12). Most pediatric patients with leukemia will receive a myeloablative regimen-which destroys the BM's ability to regenerate stem cells and necessitates a replacement by newly donated stem cells (14). As such, myeloablative approaches (which may also include total body irradiation) lead to prolonged periods of impaired mucosal barrier and neutropenia, leaving patients at risk for neutropenia-related opportunistic infection for the initial 3-6 weeks following transplantation (29). After neutrophils engraft and become stronger in number, the persisting immune deficit is lymphopenia. Lymphopenia gradually improves over the first year following transplantation.

Other preparative regimens, called reduced intensity or non-myeloablative regimens, are meant to result in reversible myelosuppression and are often used for patients with significant organ dysfunction or recent severe infection before HCT (30). These regimens consist of lower doses of chemotherapy and radiation but higher amounts of immunosuppressive drugs to prevent rejection of the new graft, so these patients may not become profoundly neutropenic $(25,31)$. For the first year after 


\begin{tabular}{|c|c|c|c|c|c|}
\hline \multirow{4}{*}{ 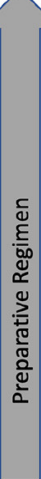 } & & $\begin{array}{l}\text { Portals of entry for } \\
\text { infection }\end{array}$ & $\begin{array}{c}\text { Duration of } \\
\text { neutropenia deficit }\end{array}$ & $\begin{array}{c}\text { Duration of } \\
\text { lymphopenia deficit }\end{array}$ & $\begin{array}{l}\text { Risk of GVHD immuno- } \\
\text { suppressive treatment }\end{array}$ \\
\hline & Myeloablative & $\begin{array}{l}\text { GI mucositis; } \\
\text { skin breaches }\end{array}$ & $\begin{array}{l}\text { Neutropenia } \\
\text { of } \\
\text { 3-4 weeks }\end{array}$ & $\begin{array}{c}\text { Gradually improves } \\
\text { over } 1 \text { year toward } \\
\text { normal }\end{array}$ & Yes \\
\hline & $\begin{array}{l}\text { Non- } \\
\text { myeloablative }\end{array}$ & Skin breaches & $\begin{array}{l}\text { Less than } \\
2 \text { weeks of } \\
\text { neutropenia }\end{array}$ & $\begin{array}{c}\text { Gradually improves } \\
\text { over } 1 \text { year toward } \\
\text { normal }\end{array}$ & Yes \\
\hline & $\begin{array}{l}\text { Reduced } \\
\text { intensity }\end{array}$ & Skin breaches & $\begin{array}{l}\text { Less than } \\
2 \text { weeks of } \\
\text { neutropenia }\end{array}$ & $\begin{array}{c}\text { Gradually improves } \\
\text { over } 1 \text { year toward } \\
\text { normal }\end{array}$ & Yes \\
\hline
\end{tabular}

FIGURE 1 | Factors associated with infections by preparative therapy intensity.

transplant, their immune deficit is tied to lymphopenia, and as with myeloablative regimens, may persist for up to a year after transplant. Figure 1 summarizes infection risk by the intensity of preparative regimen.

\section{GRAFT SOURCE TYPES}

Two main types of HCT exist-allogeneic and autologous (32). Allogeneic stem cells are those that are donated by a healthy family member or unrelated volunteer (32). Autologous stem cells are those collected from the recipient prior to preparative chemotherapy (33). Allogeneic stem cells provide the advantage of allowing for the administration of high-dose chemotherapy with the addition of foreign cells to destroy a recipient's underlying malignancy (11). In the setting of allogeneic HCT, the first-choice donor is usually a human leukocyte antigen (HLA) matched sibling donor (34). If there is not a matched sibling available, then a HLA matched unrelated volunteer donor would be utilized (34).

Donor stem cells are collected directly from the BM space in a procedure called a BM harvest (35). They may also be collected via peripheral blood after the donor is given a stem cell mobilizing agent to move stem cells into the periphery for collection (36). Additionally, umbilical cord blood (UCB) is a rich source for stem cells and is used as an HCT source (37). Umbilical cord blood units are stored in registries and are assessed for HLA compatibility before infusion (37).

Autologous grafts are often thought of as "rescue" stem cells (38). For certain types of solid tumors [especially neuroblastoma and central nervous system (CNS) tumors], high-dose myeloablative chemotherapy regimens are followed by infusion of the patient's own stem cells, termed a "rescue" procedure (39). "Rescue" stem cell infusion allows for the administration of essentially fatal doses of chemotherapy or radiation with limited periods of neutropenia (39). For these patients, the chemotherapy that precedes the autologous graft administration is what is vital in curing the underlying malignancy (39).

\section{ENGRAFTMENT}

Once a patient receives their new stem cells via a central venous catheter, the cells circulate and home to the BM cavity (40). Here, each stem cell either makes another stem cell or gradually matures to eventually make a blood cell (41). Once sufficient cells have been made, the patient has achieved engraftment (42). The period of recovery that follows is dictated by the wait for engraftment, or the new BM's ability to produce blood cells including neutrophils, red blood cells, and platelets (43). Neutrophils are key in protecting from infection and are by convention used as the time indicator for the establishment of the new BM (42). Once the neutrophil count is sustained at $>500$ cells/ $\mu$ l for 3 consecutive days, the donor stem cells are considered "engrafted," dating back to the first day of the 3-day consecutive run (42). Day to engraftment varies but in general, peripheral blood transplant recipients engraft on average at 14 days after the transplant day (known as day 0), BM recipients on day 14-21 days, and umbilical cord recipients on day 21-28 (4447). For patients who receive autologous transplants, the time to engraftment is dependent on preparative therapy and underlying disease and typically ranges from 10 to 21 days $(48,49)$. Patients who do not engraft by day +42 following transplant are likely not to engraft at all, so this time point is considered the definition of graft failure (50).

The period immediately following the completion of preparative therapy, but before neutrophil recovery, is a high-risk period for infections (51). Prolonged neutropenia, mucosal barrier breakdown, central line presence, regimenrelated toxicity (lung, renal, gastrointestinal, hepatic, and/or cardiac toxicities among others), and the altered microbiome all contribute to infection risk (52). Cell count reaches a nadir between 5 and 7 days after the preparative therapy and is often the time point when a critical care provider may encounter an HCT patient in need of intensive care secondary to infectious etiology (51).

As oral or gastrointestinal mucositis evolves, patients are at risk for infection by enteric Gram-negative bacilli, oral Grampositive organisms, and gastrointestinal streptococcal species 
(21, 53). Septic shock in HCT patients can lead to high mortality rates, in particular when the originating bacterium is a Gram-negative organism (51). Patients remain at risk for infection with esophageal or enteric Candida species during this time (54). However, diagnosis of bloodstream yeast infections can be difficult to confirm despite frequent blood culturing. Sepsis from hepatosplenic or disseminated candidiasis can have delayed diagnosis and as a result poor response to therapy, once therapy is started (54). Sepsis from disseminated mold infections such as aspergillosis, mucormycosis, or fusariosis can carry mortality rates higher than 50\% (55). Mucositis, combined with the absolute neutropenia and lymphopenia that can occur prior to engraftment, can lead to particularly severe reactivations of herpes simplex virus (HSV) oral infections, so patients often receive some form of viral prophylaxis (56). Viral reactivation by human herpesvirus 6 (HHV6) during neutropenia can lead to a fever of unknown origin that prolongs neutropenia (57).

The source of graft is an important factor in dictating this risk of infection, as each source is associated with a different length of time to engraftment and graduation from the most highrisk period for infection $(42,58)$. Prior studies have identified HCT using UCB as a donor source as a particularly highrisk graft due to delayed hematopoietic recovery and increased day 100 mortality (59). Additionally, Young et al. confirm that as peripheral blood transplants show the earliest engraftment, these patients often seem to suffer fewer infectious disease complications (9). Interestingly, when Barker et al. compared the infection risk in a cohort of pediatric patients who underwent HCT with unmanipulated BM or UCB graft, they found a comparable risk of bacterial and fungal infection between the two groups but higher risk of viral infection in the UCT group (60). This demonstrates that although each patient's risk factors must be taken into consideration, a general understanding of time to engraftment by graft source is a good estimator of the risk of infection.

\section{GRAFT-VS.-HOST-DISEASE}

Graft-vs.-host-disease (GVHD) is a major cause of morbidity and mortality after allogeneic HCT, and a major risk factor for opportunistic infections (61). In general, the acute form of GVHD (aGVHD) occurs after engraftment within the first 100 days following HCT, while chronic GVHD occurs afterward (62). There may be some overlap between the acute and chronic forms of GVHD. Acute GVHD occurs when allogeneic transplanted cells recognize recipient antigens as foreign (63). Although there is much effort to match the best donor to the recipient based on HLA typing prior to transplantation, there may remain numerous minor antigens expressed by the recipient that are not tested for a match to the donor (64). Therefore, donor cells may attack or destroy recipient cells (65). Common anatomic sites for acute GVHD include the skin and liver, gastrointestinal tract (65). The etiology of chronic GVHD (cGVHD) is less understood than aGVHD but is due to T-lymphocyte imbalances and T-cell autoreactivity $(66,67)$. Most but not all patients who develop
cGVHD have had aGVHD which can involve the skin, liver, eyes, and lungs among other organ systems (66).

Methods to decrease the risk of GVHD include graft manipulation and immunosuppressive medications $(68,69)$. Tcell depletion (TCD) of the BM or peripheral blood involves removing cyto-reactive $\mathrm{T}$ cells, after procurement of the graft (68). However, these same $\mathrm{T}$ cells are important for protection against bacterial, viral, and fungal infections (26). Van Burik et al. studied the development of infection by graft source in 404 adult patients and reported that the rate of infection did not differ between the TCD grafts and conventional GVHD prevention approaches; however, there was a greater incidence of severe CMV and aspergillosis in that patient cohort (70, 71). Again, an independent risk factor for infection was the development of severe acute GVHD (70). Therefore, for patients who receives a TCD graft, providers should be aware of these infectious risk factors.

Immunosuppressive medications given just prior to HCT and for months afterward is the main method to decrease the risk of GVHD (69). Active GVHD is treated with added immunosuppression, usually first with steroids and then with other stronger immune-suppressive drugs (67, 72). Immunosuppression to facilitate the acceptance of the new immune system and prevent the development of GVHD is given for 3-6 months following transplantation and then tapered off if no GVHD has developed (73). Both GVHD itself (by destroying the lymphoid microenvironment) and GVHD therapies (which are further immunosuppressive) place patients at risk for opportunistic infections (21, 74). Unlike solid organ transplant, however, allogeneic HCT patients do not require lifelong immunosuppression, as the recipient eventually develops tolerance of the donor cells (73). Since autologous transplant patients receive their own stem cells, they do not require immunosuppressive therapy after transplant (75).

\section{IMMUNE RECONSTITUTION}

After neutrophil engraftment, the patient remains at extraordinarily high risk for bacterial, viral, and fungal infections since the immune system is still undergoing gradual reconstitution, which takes at least a year from transplant (76). It is important to understand that although engraftment is defined by neutrophil recovery, the components of the immune system are not entirely re-established as impaired cellular and humoral immunity persists (77). Neutrophils, monocytes, and NK cells are the initial cells that recover, followed by red cell and platelet recovery (78). Immune suppression delays this process further (78). Generally, patients receive immune suppression for 3-6 months after allogeneic HCT (69). For patients who develop aGVHD or cGHVD, immune suppression needs to be continued longer, often for years (67).

After engraftment but prior to full immune system reconstitution, impaired opsonization of encapsulated bacteria and central venous line presence all remain important risk factors for infections (76). 
After engraftment, when there is the persistence of functional lymphopenia, the frequency of viral infections increases (79). Improved lymphopenia and T-cell competence do not occur until at least a year after HCT (79). Thus, this period places patients at risk for cytomegalovirus (CMV) viremia, varicellazoster virus (VZV) shingles infections, and post-transplant lymphoproliferative disorder (PTLD) from Epstein Barr virus (EBV) (79). Although bacterial bloodstream infection remains the leading cause of organ failure, viral infections can be associated with high rates of mortality due to T-cell immune incompetence, which can persist for weeks to months following transplantation $(5,53)$. Bacterial infections are not uncommon but are more frequent in the early pre-engraftment phase and may be decreased with the use of prophylactic antibiotics (8).

\section{SURVEILLANCE INFECTIOUS DISEASE TESTING}

To understand a patient's infection risk prior to HCT extensive infectious disease testing is performed prior to the onset of preparative therapy (80). This includes testing of both the donor and the recipient (80). Test results from the recipient indicate whether any infection already exists that may pose a risk for reactivation after transplant (80). Positive test results from the donor that are discordant (negative) with the donor indicate whether the recipient is at risk for a primary viral infection acquired from the donor after transplant (81).

Tests include screening for previously acquired viral infections, including hepatitis B, hepatitis C, human immunodeficiency virus (HIV), human T-cell lymphotropic virus type 1 (HTLV), West Nile virus, syphilis, Trypanosoma cruzi, and since 2020, coronavirus disease 2019 (Covid-19) (21). All patients also undergo viral serology testing of HSV, VZV, EBV, and $\mathrm{CMV}$ to understand the possibility of reactivation during periods of immunosuppression (80). Active CMV infections, in particular, are known to portent poor outcomes after transplant and thus must be treated prior to proceeding with HCT (82). Barker et al. noted that positive recipient CMV status prior to transplant was associated with a 1.3 higher fold risk of serious infection, in a pediatric patient cohort of 136 patients (60).

Transplant candidates who live in or have spent time in high-risk areas will have extra testing prior to transplant (83). Depending on the specific geographic risks of an individual patient, they may be screened for endemic pathogens such as Strongyloides stercoralis, Coccidioides species, Histoplasma capsulatum, Toxoplasma gondii, and malaria (81).

Donor serology testing prior to transplant parallels candidate testing (21). Geographic screening is similar to that of the recipient and is inclusive of the infectious disease assessment for the expected recipient (83). Donor screening, depending on the type of graft, must be completed at least 7-30 days prior to stem cell collection. Screening includes both lab work and medical history with travel history noted (21). Infections such as HIV, acute CMV, acute hepatitis A, untreated active or latent tuberculosis, toxoplasmosis, and Zika virus are considered contraindications to donation (81). There may also be other infections that will need to be considered and tested for on a caseby-case basis (21). Most testing guidelines mirror blood donation standards (21).

Prior to HCT, patients also undergo radiological testing for evidence of any infection which may include computed tomography (CT) imaging of their chest and sinuses to screen for occult infection (84). For patients who have findings of infection by CT chest or sinus, transplant is delayed for diagnostic testing and/or anti-microbial treatment, with the goal of control or resolution of the infectious disease prior to initiating preparative therapy (85). It is known that patients with any active infection at the time of transplant have poorer outcomes, as the infection will likely worsen during the neutropenic phase of the transplant course (86).

Prior to the availability of azoles, proceeding with transplant with a known active fungal infection such as invasive aspergillosis or disseminated candidiasis led to poor outcomes and was widely considered a contraindication to HCT (87). Now, patients achieve comparable overall survival, non-relapse mortality, and relapse-free survival with appropriate pre-transplant antifungal treatment (88). Therefore, a history of active fungal infection prior to transplant is now tolerated during the pre-transplant assessment period, and patients may proceed into transplant after successful treatment with at least 4 weeks of anti-fungal therapy and radiographic resolution (or in some cases stability) of the infectious infiltrate (89). Some of these patients go on to receive additional antifungal medications during transplant (87).

Patients undergo surveillance diagnostic testing for certain viral infections (CMV, EBV, adenovirus) throughout the HCT process, with the most frequent surveillance occurring approximately weekly prior to the 100-day mark (90). Among those three viral infections, CMV is particularly known to present as a late-onset viral infection (91).

Figure 2 highlights how factors associated with HCT contribute to infection risk.

\section{PROPHYLACTIC ANTIMICROBIAL USE}

Antimicrobial prophylaxis is important to prevent opportunistic infections during HCT (92). Based on a patient's pretransplant risk characteristics, prophylactic anti-infective agents are initiated with the start of the preparative regimen and may include antibacterial, antiviral, and/or antifungal prophylaxis $(10,29)$.

In pediatric centers, guidelines for which bacterial agents to use for prophylaxis differ, but as a general rule HCT patients begin a fluoroquinolone a few days before HCT and continue the fluoroquinolone until neutrophils recover to a sustained value of $>500$ cells/ $\mu$ l (93-95).

Fungal infections (particularly Aspergillus species) can occur at any time during the transplant process but are often associated with prolonged neutropenia and particularly corticosteroid use $(53,96)$. However, many anti-fungal azole agents cannot be dosed during the chemotherapy portion of preparative therapy due to risks of potentially fatal drug-drug interactions and unacceptable hepatotoxicity (97). Therefore, patients 


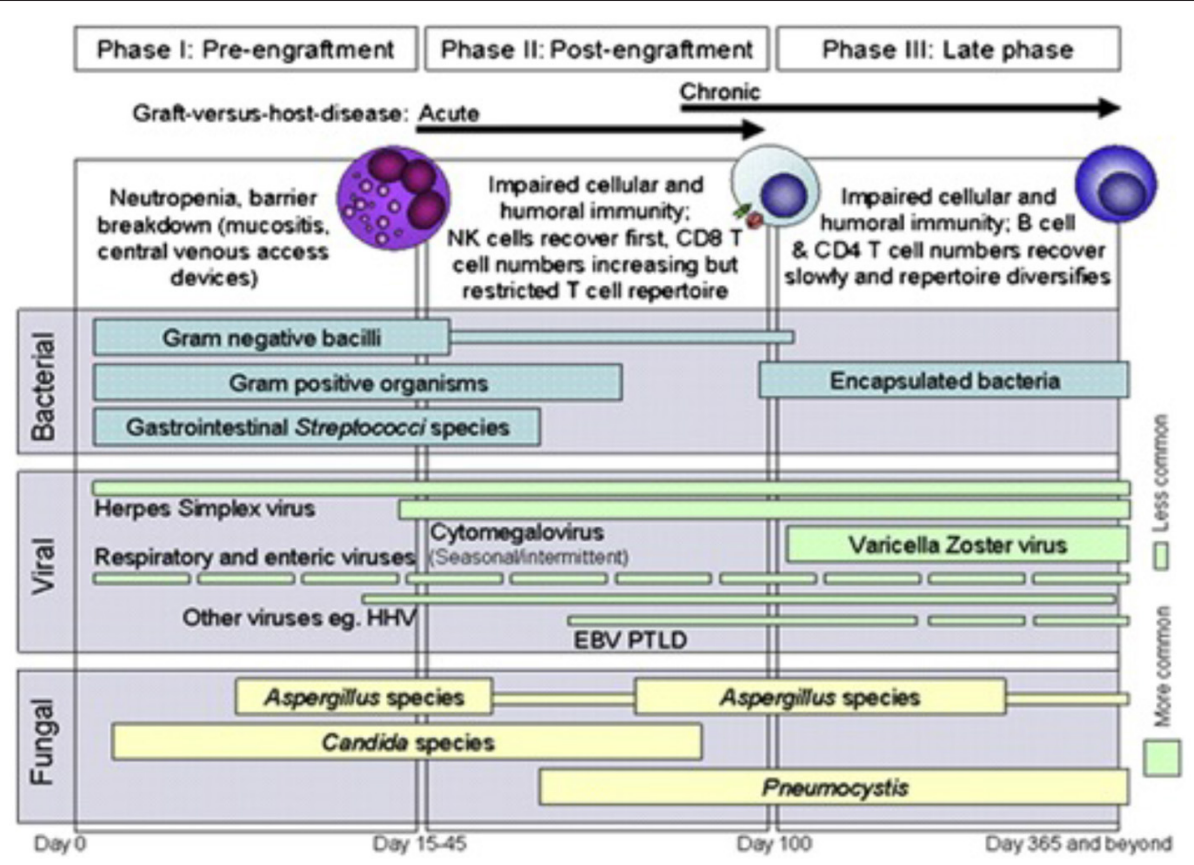

FIGURE 2 | Phases of opportunistic infections among allogeneic HCT recipients. EBV, Epstein-Barr virus; HHV6, human herpesvirus 6; PTLD, post-transplant lymphoproliferative disease. Reprinted from Tomblyn et al. (21). Copyright 2009 by Elsevier, Reprinted with permission.

often are placed on a broad spectrum echinocandin until chemotherapy completes, after which patients resume their prior prophylactic antifungal of choice given their transplant characteristics $(96,98)$.

Antiviral prophylaxis is used for patients at risk for CMV reactivation (transplant recipient is seropositive) or primary infection (donor is seropositive when the recipient is seronegative for prior infection) (99). Most centers utilize acyclovir or valacyclovir for this purpose (74). Adult patients receive letermovir in some centers, and this therapy may or may not cross over into pediatric transplant in coming years (100). Finally, patients remain on Pneumocystis jirovecii pneumonia (PJP) prophylaxis until 1 -year following transplantation as the T-cell repertoire remains restricted (101).

\section{THE GASTROINTESTINAL MICROBIOME}

Antimicrobial resistance and antibiotic stewardship are important facets to providing care for HCT patients (102). Due to preparative chemotherapy, mucosal damage, and frequent administration of empiric antimicrobials, the process of HCT is associated with severe intestinal dysbiosis (103). The rich diversity of the gut microbiome is disrupted and this process may allow for a single, often resistant, strain of bacteria to dominate (103). This loss of diversity is associated with increased overall mortality (104). The predominant mechanism for bacteremia following HCT is translocation of bacteria from the oral or gastrointestinal tract (105). Vancomycin-resistant Enterococcus and gram-negative bacteria can be associated with significant morbidity (105). As such, it is often routine practice to obtain weekly VRE surveillance rectal swabs for HCT recipients not known to be colonized with VRE $(106,107)$. Subsequently, for patients with known VRE colonization, it is imperative to consider whether to initiate VRE-active agents such as linezolid or daptomycin with fevers (108). Balancing successful prophylactic antimicrobial use with maintenance of the gastrointestinal microbiome is a continuous effort for transplant providers. An important future direction includes expanding understanding of other organ specific microbiomes including the oropharyngeal, dental, skin, and lung microbiomes.

\section{VACCINATION AFTER TRANSPLANTATION}

After HCT, patients do not have appropriate humoral or cellmediated responses to immune insults (109). It is challenging to ensure protective immunity during this period of profound immunosuppression (110). Although ensuring adequate vaccination prior to transplant is helpful, all HCT patients require revaccination after transplant (109). If the HCT patient is receiving routine childhood vaccinations prior to HCT, they can receive inactivated vaccines no sooner than 2 weeks prior to preparative therapy and live vaccines no sooner than 4 weeks prior to preparative therapy (109).

Patients require reimmunization after HCT, which generally begins 1 year after HCT at which point their immune system has reconstituted sufficiently to ensure an adequate response to the vaccine (110). A notable exception is the non-live influenza vaccine which is given on day 60 or later after HCT (111). Vaccines given at 1 year all contain inactive organisms 
or parts of organisms (110). Live vaccines are administered 2 years after HCT to prevent uncontrolled proliferation of attenuated viral strains, as long as the patient is no longer receiving immune suppression (112). Serologic testing can be performed before measles, rubella, and varicella re-vaccination (113). The Bacillus Calmette-Guerin tuberculosis vaccine, oral poliovirus vaccine, cholera vaccine, oral typhoid vaccine, live zoster vaccine, yellow fever vaccine, and oral rotavirus vaccine are all contraindicated (114).

Vaccines may be given to those with GVHD (115). For patients who receive rituximab as part of their preparative therapy, B-cell recovery does not occur until 6-9 months after HCT (115).

Many providers may choose to trend the absolute CD4 and/or CD19 count as a surrogate marker for signs of $\mathrm{T}$ and $\mathrm{B}$ cell recovery, respectively (109). Often, vaccinations are deferred until the CD4 count is $>200 / \mu \mathrm{l}$ and the CD19 count is $>20 / \mu 1$, although the use of these tests is highly variable to guide vaccination time points and can be center specific (116).

As is evident, there is yet much to be learned about optimizing vaccination schedule and discovering new markers of immune response. For the PICU provider, knowing that the HCT recipient is more than 2 years out from transplant suggests that their vaccine schedule may be up to date, and glancing at their immunization history could confirm that. Knowing that the HCT recipient is between 1 and 2 years from transplant suggests the patient may have received non-live vaccines. For the HCT patient who is not yet 1 year from the transplant procedure, the current illness may include infections with otherwise vaccine-preventable encapsulated organisms.

\section{CLINICAL CASE EXAMPLES}

It can be challenging to understand the exquisite state of an HCT patient's immune system during times of severe infections requiring PICU care. The important phases of HCT to consider when assessing a patient's infection risk and status are categorized into pre-preparative therapy, during preparative therapy, before engraftment, and after engraftment phases. Figure 3 highlights the shifting infectious risk of the HCT patient based on a variety of characteristics. We present a case-based overview and review of the management of the pediatric HCT recipient in the PICU with infectious complications by the phase of HCT. As immunosuppression plays a special role throughout HCT, it is discussed after the case vignettes. The following seven hypothetical cases are presented in order along the timeline for transplant.

\section{Case Presentation 1, Prior to Preparative Therapy for Transplant}

A 2-year-old boy with a history of severe aplastic anemia (SAA) is undergoing pre-transplant infectious surveillance in anticipation of a myeloablative BMT. He initially presented with autoimmune hemolytic anemia (AIHA) and immune thrombocytopenia (ITP) following a viral illness and was treated for AIHA and ITP with intravenous IVIG, rituximab, and steroids. Due to the presence of autoimmune hepatitis, he was also being treated with azathioprine. His cytopenias progressed despite therapy over the next several months. He eventually developed pancytopenia leading to his diagnosis of SAA after BM biopsy showed cellularity of $<5 \%$ (normal for age $90-95 \%$ ). Pre-transplant infectious disease surveillance was unremarkable except for an abnormal chest CT. A $2.1 \times 1.5 \mathrm{~cm}$ round subpleural mass was noted in the left lower lobe with ground-glass attenuation in the left perihilar region. On physical examination, the patient was afebrile, breathing comfortably in room air with a normal respiratory rate and oxygen saturation. Question: How should this patient be managed? Answer: HCT should be delayed while diagnostic procedures can be performed (bronchoscopy with bronchoalveolar lavage) and the patient receives applicable treatment for possible fungal pneumonia.

\section{Case Discussion}

This patient has multiple risk factors for opportunistic and difficult-to-treat infections. First, his underlying diagnosis is aplastic anemia. Despite the misnomer, aplastic anemia is a failure of the $\mathrm{BM}$ to produce (or autoimmune destruction of) hematopoietic stem cells that later differentiate into leukocytes, red blood cells, and platelets. Therefore, depending on the timing of diagnosis, SAA patients may have spent weeks, months, or even years neutropenic by the time they come to HCT. The length of time between diagnosis and definitive treatment is related to survival outcomes (117). Additionally, the best mode of therapy in pediatric patients is to undergo a matched sibling

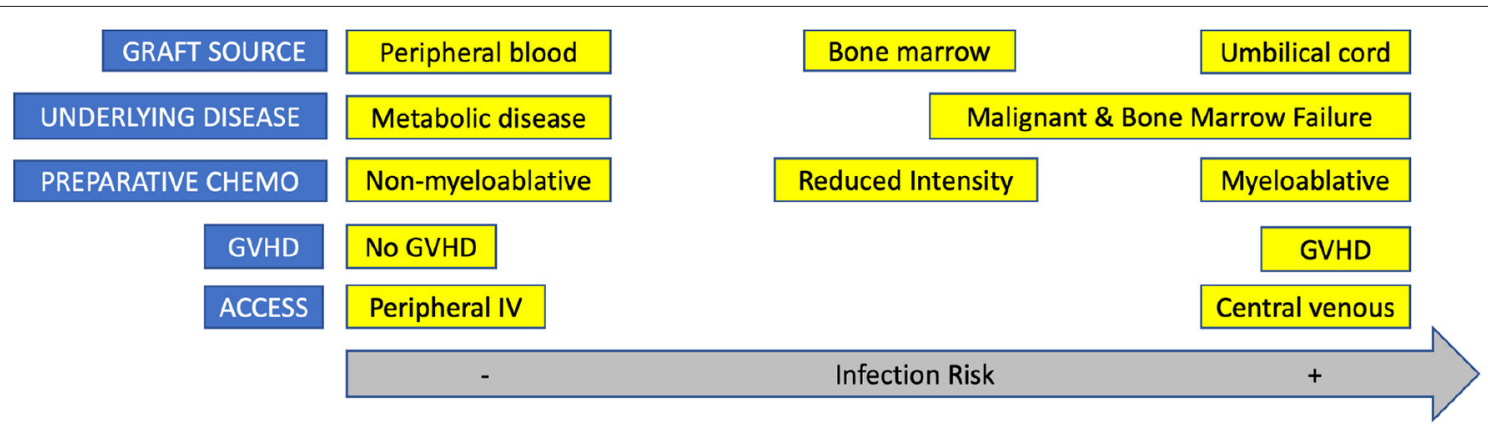

FIGURE 3 | HCT characteristics and risk for infection. 
HCT. In cases where a matched sibling is not available (75$80 \%$ of cases), patients are maintained on immunosuppressants typically consisting of anti-thymocyte globulin or cyclosporineagents which can cause lymphopenia. This patient, who has a diagnosis of hepatitis-induced SAA, is also being treated with azathioprine which is immunosuppressive. Therefore, in this setting, this patient's diagnosis, as well as its subsequent treatment, are considered risk factors. This clinical vignette highlights the infectious risk factors of HCT patients even before they come to transplant, which reveals the risk factors inherent to the disease and its treatment. The provider needs to consider an HCT patient's risk factors that may exist outside the HCT process, which in and of itself is a risk factor.

\section{Case Presentation 2, During Preparative Therapy Prior to Transplant}

An 8-year-old boy, with a history of relapsed acute myeloid leukemia (AML) after an UCT, is admitted to the hospital to begin preparation for a second HCT, using a second UCB graft that will be infused in 7 days. On the third day of his myeloablative preparative chemotherapy, 4 days prior to infusion of his second transplant, he develops a temperature of $39.8^{\circ} \mathrm{C}$. On examination, he is hypotensive (blood pressure is $64 / 32 \mathrm{mmHg}$ ) and tachycardic at 150 beats/min. His lungs are clear to auscultation. Blood cultures are obtained from his central line, and he is started on broad-spectrum empiric antibacterial antibiotics. He receives multiple fluid boluses and his hemodynamic status improves. Question: What is the likely underlying etiology of his hemodynamic change? Answer: Grampositive infection of his central venous catheter.

\section{Case Discussion}

This patient is in the midst of his myeloablative preparative chemotherapy prior to his second transplant and is likely pancytopenic. This period marks the beginning of mucosal breakdown that can lead to opportunistic infections, as the preparative therapy affects rapidly dividing cells such as the mucosal surfaces. This effectively makes a patient's own commensurate bacteria a potentially fatal source for infection. In particular, oral streptococcal organisms can cause bloodstream and neck soft tissue infections during the first 3 weeks after transplant. As all patients undergoing HCT have a central venous access catheter throughout transplantation, it is important to consider the possibility of a catheter-associated infection with each fever, as described in the case presentation. All neutropenic HCT recipients who develop a fever are treated empirically with an antibiotic with anti-pseudomonal \pm Gram-positive activity. In this setting, gram-positive bacteria are most commonly isolated. Coagulase-negative staphylococci may not be that virulent, but Staphylococcus aureus can be the cause of the severe hemodynamic collapse. Vancomycin is indicated in this setting and should be added to anti-pseudomonal therapy when there is an abrupt decline in hemodynamic status. For patients with central venous access catheters and hemodynamic stability, with cellulitis or pain around the indwelling catheter skin exit site, the addition of vancomycin is also appropriate.

\section{Case Presentation 3, Two Weeks After Transplant}

A 6-year-old girl with a history of relapsed AML underwent a myeloablative matched sibling BMT 14 days ago. She is an inpatient in the hospital awaiting engraftment, receiving supportive care with a prophylactic fluoroquinolone antibiotic and transfusions until count recovery, when she suddenly develops fluid-refractory hypotension (blood pressure 70/30 $\mathrm{mm}$ $\mathrm{Hg}$ ). On examination, she is noted to be febrile to $39.6^{\circ} \mathrm{C}$ and tachycardic at 145 beats $/ \mathrm{min}$. She is noted to have crackles on lung auscultation and has a distended but soft abdomen. She is urgently transferred to the PICU where she eventually requires support with multiple vasopressor agents and mechanical ventilation. She is started on broad-spectrum intravenous antibacterial antibiotics and undergoes CT imaging of her abdomen, which identifies colitis. Question: What is the likely underlying etiology of her sudden hemodynamic collapse? Answer: Gram-negative sepsis secondary to translocation of gut bacterial flora.

\section{Case Discussion}

This patient developed rapidly deteriorating gram-negative septicemia. She received a matched sibling BMT 2 weeks ago and had likely not yet achieved engraftment. Therefore, she is at risk for severe opportunistic infections. For one, the gut microbiota are known to play a part in transplantrelated infectious complications. She has also likely already experienced considerable mucositis and likely has some degree of epithelial cell damage in the gut which creates an environment in which commensal bacteria can invade the mucosa and submucosa to enter the bloodstream. Additionally, the preparative chemotherapy destroys circulating granulocytes and monocytes which are needed for gut healing (118). The colitis noted on the CT scan likely describes that mucosal injury with an associated influx of inflammatory mediators. During this phase of HCT where the patient has received preparative chemotherapy but has not engrafted their new cells, the provider must recognize the risk the patient is at from commensal aerobic and anaerobic bacterial organisms.

In the setting of an unidentified bacterial species or what becomes presumed culture-negative sepsis, many HCT recipients will receive double coverage with antibiotics directed at Gramnegative bacteria and anaerobic bacteria (119). An antipseudomonal beta-lactam can be escalated to a carbapenem (for anaerobic coverage). Additionally, an aminoglycoside (for gram-negative and some antipseudomonal coverage) is often initiated until hemodynamic stability is achieved and a causative organism identified. In the case of an unstable HCT patient, vancomycin can be added for better gram-positive gut flora (i.e., enterococcal) coverage, and anti-fungal coverage can be added or broadened to include coverage of regular candidal yeasts, fluconazole-resistant yeasts, and/or molds. As in this example, CT imaging of the abdomen is particularly important to perform and was concerning for neutropenic bacterial enterocolitis with possible intestinal necrosis. 


\section{Case Presentation 4, One Month After Transplant}

An 11-year-old boy with an immunodeficiency disorder underwent an HLA matched unrelated BMT. His transplant course was relatively uncomplicated and he had appropriate count recovery. On day 26 after his transplant, he developed high persistent fevers and a gradual change in mental status leading to florid encephalopathy. He was transferred to the PICU after experiencing a short tonic-clonic seizure and inability to maintain his airway. After intubation in the PICU, he underwent a lumbar puncture that revealed CSF findings of $5 \mathrm{WBC}, 0 \mathrm{RBC}, 96 \mathrm{mg} / \mathrm{dl}$ protein, and $47 \mathrm{mg} / \mathrm{ml}$ glucose (greater than two-third of the blood sugar level). CSF bacterial aerobic and anaerobic cultures remained negative. He was started on broad-spectrum antimicrobials including empiric antifungal and antiviral agents. Question: What viral infection is an emerging cause of encephalopathy in the HCT population? Answer: HHV6.

\section{Case Discussion}

This case highlights the importance of maintaining a broad viral differential diagnosis, particularly for cases of encephalitis. HHV6 is a ubiquitous entity, with most individuals experiencing a primary infection in childhood and with some immunosuppressed individuals experiencing reactivation, as may be the case with HCT. HHV6 can remain latent in multiple organ systems including the CNS and in some cases may integrate its DNA into the human genome (120). Typical findings on MRI include limbic encephalitis but are not specific. The diagnosis is best made by an astute provider sending CSF DNA viral PCR studies (121). There remain no guidelines for the best course of therapy (122). Since HHV6 has $~ 75 \%$ DNA homology to $\mathrm{CMV}$, various antiviral medications used to treat CMV infections can be used (123). It is important to note that the usual toxicities associated with use of these antiviral agents, such as BM suppression or kidney injury, can complicate treatment courses.

\section{Case Presentation 5, Six Months After Transplant}

A 13-year-old girl with a history of relapsed acute lymphoblastic leukemia (ALL) underwent an UCT 6 months ago. She is engrafted without evidence of GVHD and is no longer receiving immunosuppression. She presents to the emergency department with a fever of $40.1^{\circ} \mathrm{C}$ and tachypnea. Her saturations are $88 \%$ while breathing room air so she is placed on low flow oxygen via nasal cannula. On examination, she is in obvious distress with increased work of breathing and decreased breath sounds in the left lower lung base with rhonchi. A chest radiograph is obtained which shows a large opacity in the left lower lung field with air-bronchograms and trace pleural effusion. Question: What vaccine-preventable infection should be considered? Answer: Streptococcus pneumoniae.

\section{Case Discussion}

This patient was started on broad-spectrum antibacterial antimicrobial agents upon transfer to the PICU. A sputum sample was obtained which showed the predominant presence of gram-positive diplococci consistent with $S$. pneumoniae. A sputum culture confirmed the diagnosis. The differential diagnosis for bacterial causes for pneumonia in the immunocompromised HCT patients includes communityacquired bacteria such as S. pneumoniae, Mycoplasma pneumoniae, and Haemophilus influenzae. Influenza $\mathrm{A}$ and $\mathrm{B}$ viruses should be considered during annual flu seasons. Opportunistic fungi including $P$. jirovecii, Aspergillus spp., and Cryptococcus spp. Geographically-restricted fungi such as Coccidioides immitis, Blastomyces dermatitidis, and $H$. capsulatum should also be considered. Although not performed in this case, providers should consider bronchoalveolar lavage as a diagnostic tool for identifying either a community-acquired or opportunistic microorganism when sputum cultures do not lead to finding the reason for infection in the lungs (124-126).

\section{Case Presentation 6, 10 Months After Transplant}

A 13-year-old boy with a history of SAA underwent a matched unrelated BMT 10 months ago. He is engrafted and has no history of GVHD. He is not receiving immunosuppressive therapy and remains on PJP prophylaxis per routine supportive care guidelines. He presents to his hematologist with a recent history of thrombocytopenia and a new-onset excruciating headache refractory to over the counter analgesia. $\mathrm{He}$ is admitted to the hospital for platelet transfusion and further imaging. Unfortunately, he experiences a sudden neurologic decline necessitating intubation. A brain MRI reveals numerous enhancing lesions throughout both cerebral and cerebellar hemispheres with punctate microhemorrhages and surrounding vasogenic edema. He undergoes extensive infectious disease testing of blood and cerebral spinal fluid. On lumbar puncture, he is noted to have elevated intracranial pressure (ICP) with a normal ophthalmologic exam. On expanded travel history, he is identified to have lived in China for multiple brief periods during his childhood, which assists in identifying his diagnosis. Question: What is the likely underlying infectious etiology of his MRI findings and neurologic decline? Answer: CNS Toxoplasmosis.

\section{Case Discussion}

This patient presented with a CNS T. gondii infection, a somewhat unusual infection even in the heavily immunosuppressed BMT population and one that is often fatal. He was at risk for Toxoplasma infection because his Pneumocystis prophylaxis was changed from Bactrim to dapsone earlier in his post-transplant course. This case imparts an important lesson that non-sulfa-based Pneumocystis prophylaxis regimens do not protect against toxoplasmosis or nocardiosis or extrapulmonary pneumocystosis. Pneumocystis prophylaxis with inhaled pentamidine can lead to upper lung lobe Pneumocystis infections, where the nebulized pentamidine does not penetrate well.

For this case patient's infection, he was treated with a 6week course of pyrimethamine, leucovorin, and sulfadiazine followed by maintenance pyrimethamine and clindamycin for 
12 months. As T. gondii is known to have increased prevalence in geographical areas with cat exposure and possible food contamination with cysts, this case highlights the importance of soliciting a patient's full travel and pet exposure (127). It is important for the PICU provider to remain abreast of possible exposures a pediatric BMT patient may have and how that might cause systemic infection. Animals commonly kept as pets such as lizards, snakes, turtles, and other reptiles are known to carry and possibly spread Salmonella and Cryptosporidium parvum (128). Baby chicks and ducklings are known to carry and possibly spread Campylobacter jejuni (129). Cats are known to shed T. gondii in their feces as above and may carry Bartonella henselae (130). Finally, household dogs may be infected with parasites such as Toxocara canis (128).

\section{Case Presentation 7, 18 Months After Transplant}

A 9-year-old boy with a history of cerebral adrenoleukodystrophy (c-ALD) underwent an UCT approximately 18 months ago. His HCT course was complicated by autoimmune cytopenias for which he received multiple therapies over the last year including rituximab, IVIG, mycophenolate mofetil (MMF), daratumumab, and steroids. He presented to the ED with increased work of breathing and oxygen saturation of $86 \%$ while breathing room air. On auscultation of his lungs, he had poor aeration bilaterally and copious coarse breath sounds. His Covid-19 testing was negative. He was transferred to the PICU for respiratory support. At the time of admission, he was not on any prophylactic antimicrobial agents. Question: What is the likely underlying etiology of his sudden respiratory distress? Answer: Pneumocystis pneumonia.

\section{Case Discussion}

As this patient was over 1 year from HCT, PJP prophylaxis had been discontinued per standard procedure at the 1-year transplant clinic visit. However, he then developed autoimmune cytopenias and should have had Pneumocystis prophylaxis restarted when immunosuppressive treatments were resumed. In his case, he remained at risk for PJP while receiving highly immunosuppressive therapy for his autoimmune cytopenia and should have continued to receive prophylaxis due to continuing

\section{REFERENCES}

1. Duarte RF, Labopin M, Bader P, Basak GW, Bonini C, Chabannon $\mathrm{C}$, et al. Indications for haematopoietic stem cell transplantation for haematological diseases, solid tumours and immune disorders: current practice in Europe, 2019. Bone Marrow Transplant. (2019) 54:152552. doi: 10.1038/s41409-019-0516-2

2. Tan EY, Boelens JJ, Jones SA, Wynn RF. Hematopoietic stem cell transplantation in inborn errors of metabolism. Front Pediatr. (2019) 7:433. doi: 10.3389/fped.2019.00433

3. Morgan RA, Gray D, Lomova A, Kohn DB. Hematopoietic stem cell gene therapy: progress and lessons learned. Cell Stem Cell. (2017) 21:57490. doi: 10.1016/j.stem.2017.10.010

4. Kwon R, Koutsogiannaki S, Staffa SJ, Yuki K. The outcomes of pediatric hematopoietic stem cell transplantation recipients requiring intensive care exogenous immunosuppression. It is important for providers to be aware that HCT patients must remain on PJP prophylaxis until 1 year after HCT or when patients are receiving $>20 \mathrm{mg} /$ day of steroid.

\section{DISCUSSION}

The PICU provider needs to understand the unique infectious risks present secondary to HCT and immunosuppression. Pediatric HCT patients who require PICU level care are complex and require a multisystem approach as well as a keen understanding of where they are in the transplant process. PICU providers must understand the shifting status of an HCT patient's infectious risk as they progress through the transplant process. Although immunosuppression is thought to be largely associated with the early phases of HCT, it is incumbent for the PICU provider to understand what if any immunosuppressive therapies the patient may still be receiving.

Respiratory and septic events are the main reasons HCT patients are transferred to the PICU. When evaluating these patients, it is important to also consider additional risk factors such as the presence of a central venous access catheter and the patient's time spent neutropenic and/or immunosuppressed. The care of the HCT recipient must remain focused on the likely multiorgan dysfunction that is present during times of infection. Although the clinical stability of a patient's hemodynamic status is paramount to good outcomes, providers must also consider antimicrobial stewardship. It is important to narrow antimicrobial coverage as soon as it is safe to do so (131). Use of too much antibacterial prophylaxis during neutropenia can have the deleterious effect of changing a patient's enteral microbiome (103). Pharmacists and infectious disease physicians alongside both the HCT and PICU physicians are key in maintaining this initiative. We hope this guide services as a reference for these patients when they require PICU level care.

\section{AUTHOR CONTRIBUTIONS}

All authors listed have made a substantial, direct and intellectual contribution to the work, and approved it for publication. 
8. Gea-Banacloche JC, Wade JC. Improvements in the prevention and management of infectious complications after hematopoietic stem cell transplantation. Cancer Treat Res. (2009) 144:53973. doi: 10.1007/978-0-387-78580-6 21

9. Young JH, Logan BR, Wu J, Wingard JR, Weisdorf DJ, Mudrick C, et al. Infections after transplantation of bone marrow or peripheral blood stem cells from unrelated donors. Biol Blood Marrow Transplant. (2016) 22:35970. doi: 10.1016/j.bbmt.2015.09.013

10. Young JH. Management of infectious diseases in stem cell transplantation and hematologic malignancy. Infect Dis Clin North Am. (2019). 33:xiiixv. doi: 10.1016/j.idc.2019.02.013

11. Balassa K, Danby R, Rocha V. Haematopoietic stem cell transplants: principles and indications. Br J Hosp Med (Lond). (2019) 80:339. doi: 10.12968/hmed.2019.80.1.33

12. Gyurkocza B, Sandmaier BM. Conditioning regimens for hematopoietic cell transplantation: one size does not fit all. Blood. (2014) 124:34453. doi: 10.1182/blood-2014-02-514778

13. Takami A. Hematopoietic stem cell transplantation for acute myeloid leukemia. Int J Hematol. (2018) 107:513-8. doi: 10.1007/s12185-018-2412-8

14. Saadeh SS, Litzow MR. Hematopoietic stem cell transplant in adults with acute lymphoblastic leukemia: the present state. Expert Rev Hematol. (2018) 11:195-207. doi: 10.1080/17474086.2018.1433030

15. Szade K, Gulati GS, Chan CKF, Kao KS, Miyanishi M, Marjon KD, et al. Where hematopoietic stem cells live: the bone marrow niche. Antioxid Redox Signal. (2018) 29:191-204. doi: 10.1089/ars.2017.7419

16. Damon LE. Mobilization of hematopoietic stem cells into the peripheral blood. Expert Rev Hematol. (2009) 2:717-33. doi: 10.1586/ehm.09.54

17. Copelan EA, Chojecki A, Lazarus HM, Avalos BR. Allogeneic hematopoietic cell transplantation; the current renaissance. Blood Rev. (2019) 34:3444. doi: 10.1016/j.blre.2018.11.001

18. Alter BP. Inherited bone marrow failure syndromes: considerations pre- and posttransplant. Blood. (2017) 130:225764. doi: 10.1182/blood-2017-05-781799

19. Krishnamurti L, Bunn HF, Williams AM, Tolar J. Hematopoietic cell transplantation for hemoglobinopathies. Curr Probl Pediatr Adolesc Health Care. (2008) 38:6-18. doi: 10.1016/j.cppeds.2007.10.002

20. Young NS. Current concepts in the pathophysiology and treatment of aplastic anemia. Hematology Am Soc Hematol Educ Program. (2013) 2013:76-81. doi: 10.1182/asheducation-2013.1.76

21. Tomblyn M, Chiller T, Einsele H, Gress R, Sepkowitz K, Storek J, et al. Guidelines for preventing infectious complications among hematopoietic cell transplantation recipients: a global perspective. Biol Blood Marrow Transplant. (2009) 15:1143-238. doi: 10.1016/j.bbmt.2009.06.019

22. Drexler B, Tichelli A, Passweg JR. [Bone marrow failure]. Ther Umsch. (2019) 76:523-9. doi: 10.1024/0040-5930/a001123

23. Boxer LA. How to approach neutropenia. Hematology Am Soc Hematol Educ Program. (2012) 2012:17482. doi: 10.1182/asheducation.V2012.1.174.3798251

24. D'Souza A, Lee S, Zhu X, Pasquini M. Current use and trends in hematopoietic cell transplantation in the United States. Biol Blood Marrow Transplant. (2017) 23:1417-21. doi: 10.1016/j.bbmt.2017.05.035

25. Allison TL. Immunosuppressive therapy in transplantation. Nurs Clin North Am. (2016) 51:107-20. doi: 10.1016/j.cnur.2015.10.008

26. Whangbo JS, Antin JH, Koreth J. The role of regulatory T cells in graftversus-host disease management. Expert Rev Hematol. (2020) 13:14154. doi: 10.1080/17474086.2020.1709436

27. Leliefeld PH, Wessels CM, Leenen LP, Koenderman L, Pillay J. The role of neutrophils in immune dysfunction during severe inflammation. Crit Care. (2016) 20:73. doi: 10.1186/s13054-016-1250-4

28. de Pablo R, Monserrat J, Prieto A, Alvarez-Mon M. Role of circulating lymphocytes in patients with sepsis. Biomed Res Int. (2014) 2014:671087. doi: 10.1155/2014/671087

29. Kao RL, Holtan SG. Host and graft factors impacting infection risk in hematopoietic cell transplantation. Infect Dis Clin North Am. (2019) 33:31129. doi: 10.1016/j.idc.2019.02.001

30. Giralt S, Ballen K, Rizzo D, Bacigalupo A, Horowitz M, Pasquini M, et al. Reduced-intensity conditioning regimen workshop: defining the dose spectrum. Report of a workshop convened by the center for international blood and marrow transplant research. Biol Blood Marrow Transplant. (2009) 15:367-9. doi: 10.1016/j.bbmt.2008.12.497

31. Weisdorf DJ. Reduced-intensity versus myeloablative allogeneic transplantation. Hematol Oncol Stem Cell Ther. (2017) 10:3216. doi: 10.1016/j.hemonc.2017.05.002

32. Tabbara IA, Zimmerman K, Morgan C, Nahleh Z. Allogeneic hematopoietic stem cell transplantation: complications and results. Arch Intern Med. (2002) 162:1558-66. doi: 10.1001/archinte.162.14.1558

33. Sheppard D, Bredeson C, Allan D, Tay J. Systematic review of randomized controlled trials of hematopoietic stem cell mobilization strategies for autologous transplantation for hematologic malignancies. Biol Blood Marrow Transplant. (2012) 18:1191-203. doi: 10.1016/j.bbmt.2012.01.008

34. Tiercy JM. How to select the best available related or unrelated donor of hematopoietic stem cells? Haematologica. (2016) 101:6807. doi: 10.3324/haematol.2015.141119

35. Tucci F, Frittoli M, Barzaghi F, Calbi V, Migliavacca M, Ferrua F, et al. Bone marrow harvesting from paediatric patients undergoing haematopoietic stem cell gene therapy. Bone Marrow Transplant. (2019) 54:1995-2003. doi: 10.1038/s41409-019-0573-6

36. Devine H, Tierney DK, Schmit-Pokorny K, McDermott K. Mobilization of hematopoietic stem cells for use in autologous transplantation. Clin J Oncol Nurs. (2010) 14:212-22. doi: 10.1188/10.CJON.212-222

37. Berglund S, Magalhaes I, Gaballa A, Vanherberghen B, Uhlin M. Advances in umbilical cord blood cell therapy: the present and the future. Expert Opin Biol Ther. (2017) 17:691-9. doi: 10.1080/14712598.2017.1316713

38. Fish JD, Grupp SA. Stem cell transplantation for neuroblastoma. Bone Marrow Transplant. (2008) 41:159-65. doi: 10.1038/sj.bmt.1705929

39. Jain R, Hans R, Totadri S, Trehan A, Sharma RR, Menon P, et al. Autologous stem cell transplant for high-risk neuroblastoma: achieving cure with low-cost adaptations. Pediatr Blood Cancer. (2020) 67:e28273. doi: $10.1002 / \mathrm{pbc} .28273$

40. Holtick U, Albrecht M, Chemnitz JM, Theurich S, Shimabukuro-Vornhagen A, Skoetz N, et al. Comparison of bone marrow versus peripheral blood allogeneic hematopoietic stem cell transplantation for hematological malignancies in adults - a systematic review and meta-analysis. Crit Rev Oncol Hematol. (2015) 94:179-88. doi: 10.1016/j.critrevonc.2014.12.007

41. Yu VW, Scadden DT. Hematopoietic stem cell and its bone marrow niche. Curr Top Dev Biol. (2016) 118:21-44. doi: 10.1016/bs.ctdb.2016.01.009

42. Ali MY, Oyama Y, Monreal J, Winter J, Tallman M, Gordon LI. et al. Reassessing the definition of myeloid engraftment after autotransplantation: it is not necessary to see $05 \times 10(9) / 1$ neutrophils on 3 consecutive days to define myeloid recovery. Bone Marrow Transplant. (2002) 30:74952. doi: 10.1038/sj.bmt.1703741

43. Huang $\mathrm{X}$, Broxmeyer HE. Progress towards improving homing and engraftment of hematopoietic stem cells for clinical transplantation. Curr Opin Hematol. (2019) 26:266-72. doi: 10.1097/MOH.0000000000000510

44. Childs R, Clave E, Contentin N, Jayasekera D, Hensel N, Leitman S, et al. Engraftment kinetics after nonmyeloablative allogeneic peripheral blood stem cell transplantation: full donor T-cell chimerism precedes alloimmune responses. Blood. (1999) 94:3234-41. doi: 10.1182/blood.V94.9.3234

45. Baron F, Baker JE, Storb R, Gooley TA, Sandmaier BM, Maris MB, et al. Kinetics of engraftment in patients with hematologic malignancies given allogeneic hematopoietic cell transplantation after nonmyeloablative conditioning. Blood. (2004) 104:2254-62. doi: 10.1182/blood-2004-04-1506

46. Díaz MA, Villa M, Madero L, Benito A, Alegre A, FernandezRañada JM. Analysis of engraftment kinetics in pediatric patients undergoing autologous PBPC transplantation. J Hematother. (1998) 7:367-73. doi: 10.1089/scd.1.1998.7.367

47. Ruggeri A, Labopin M, Sormani MP, Sanz G, Sanz J, Volt F, et al. Engraftment kinetics and graft failure after single umbilical cord blood transplantation using a myeloablative conditioning regimen. Haematologica. (2014) 99:1509-15. doi: 10.3324/haematol.2014.109280

48. Hillier K, Cheng WS, Whittle SB, Krance R, Foster JH. Factors impacting time to engraftment in patients with high-risk neuroblastoma following autologous stem cell transplant. J Pediatr Hematol Oncol. (2020) 42:e56974. doi: 10.1097/MPH.0000000000001731

49. Oran B, Malek K, Sanchorawala V, Wright DG, Quillen K, Finn KT, et al. Predictive factors for hematopoietic engraftment after autologous 
peripheral blood stem cell transplantation for AL amyloidosis. Bone Marrow Transplant. (2005) 35:567-75. doi: 10.1038/sj.bmt.1704826

50. Quinones RR. Hematopoietic engraftment and graft failure after bone marrow transplantation. Am J Pediatr Hematol Oncol. (1993) 15:317. doi: 10.1097/00043426-199302000-00002

51. Sahin U, Toprak SK, Atilla PA, Atilla E, Demirer T. An overview of infectious complications after allogeneic hematopoietic stem cell transplantation. $J$ Infect Chemother. (2016) 22:505-14. doi: 10.1016/j.jiac.2016.05.006

52. Bearman SI, Appelbaum FR, Back A, Petersen FB, Buckner CD, Sullivan KM, et al. Regimen-related toxicity and early posttransplant survival in patients undergoing marrow transplantation for lymphoma. J Clin Oncol. (1989) 7:1288-94. doi: 10.1200/JCO.1989.7.9.1288

53. Saillard C, Blaise D, Mokart D. Critically ill allogeneic hematopoietic stem cell transplantation patients in the intensive care unit: reappraisal of actual prognosis. Bone Marrow Transplant. (2016) 51:1050-61. doi: 10.1038/bmt.2016.72

54. Girmenia C, Finolezzi E, Federico V, Santopietro M, Perrone S. Invasive Candida infections in patients with haematological malignancies and hematopoietic stem cell transplant recipients: current epidemiology and therapeutic options. Mediterr J Hematol Infect Dis. (2011) 3:e2011013. doi: 10.4084/mjhid.2011.013

55. Price TH. The current prospects for neutrophil transfusions for the treatment of granulocytopenic infected patients. Transfus Med Rev. (2000) 14:2-11. doi: 10.1016/S0887-7963(00)80111-X

56. van der Beek MT, Laheij AM, Raber-Durlacher JE. von dem Borne PA, Wolterbeek R, van der Blij-de Brouwer CS, et al. Viral loads and antiviral resistance of herpesviruses and oral ulcerations in hematopoietic stem cell transplant recipients. Bone Marrow Transplant. (2012) 47:12228. doi: 10.1038/bmt.2012.2

57. Betts BC, Young JA, Ustun C, Cao Q, Weisdorf DJ. Human herpesvirus 6 infection after hematopoietic cell transplantation: is routine surveillance necessary? Biol Blood Marrow Transplant. (2011) 17:1562-8. doi: 10.1016/j.bbmt.2011.04.004

58. Espinoza JL, Wadasaki Y, Takami A. Infection complications in hematopoietic stem cells transplant recipients: do genetics really matter? Front Microbiol. (2018) 9:2317. doi: 10.3389/fmicb.2018.02317

59. Rocha V, Cornish J, Sievers EL, Filipovich A, Locatelli F, Peters C, et al. Comparison of outcomes of unrelated bone marrow and umbilical cord blood transplants in children with acute leukemia. Blood. (2001) 97:296271. doi: 10.1182/blood.V97.10.2962

60. Barker JN, Hough RE, van Burik JA, DeFor TE, MacMillan ML, O'Brien MR, et al. Serious infections after unrelated donor transplantation in 136 children: impact of stem cell source. Biol Blood Marrow Transplant. (2005) 11:362-70. doi: 10.1016/j.bbmt.2005.02.004

61. MacMillan ML, Weisdorf DJ, Wagner JE, DeFor TE, Burns LJ, Ramsay NK, et al. Response of 443 patients to steroids as primary therapy for acute graft-versus-host disease: comparison of grading systems. Biol Blood Marrow Transplant. (2002) 8:387-94. doi: 10.1053/bbmt.2002.v8.pm12171485

62. Jagasia MH, Greinix HT, Arora M, Williams KM, Wolff D, Cowen EW, et al. National institutes of health consensus development project on criteria for clinical trials in chronic graft-versus-host disease: I. The 2014 diagnosis and staging working group report. Biol Blood Marrow Transplant. (2015). 21:389.e1-401.e1. doi: 10.1016/j.bbmt.2015.02.025

63. Ghimire S, Weber D, Mavin E, Wang XN, Dickinson AM, Holler E. Pathophysiology of GvHD and other HSCT-related major complications. Front Immunol. (2017) 8:79. doi: 10.3389/fimmu.2017.00079

64. Spellman S, Warden MB, Haagenson M, Pietz BC, Goulmy E, Warren $\mathrm{EH}$, et al. Effects of mismatching for minor histocompatibility antigens on clinical outcomes in HLA-matched, unrelated hematopoietic stem cell transplants. Biol Blood Marrow Transplant. (2009) 15:856-63. doi: 10.1016/j.bbmt.2009.03.018

65. Nassereddine S, Rafei H, Elbahesh E, Tabbara I. Acute graft. Anticancer Res. (2017) 37:1547-55. doi: 10.21873/anticanres.11483

66. Lee SJ, Vogelsang G, Flowers ME. Chronic graft-versus-host disease. Biol Blood Marrow Transplant. (2003) 9:215-33. doi: 10.1053/bbmt.2003. 50026

67. Flowers ME, Martin PJ. How we treat chronic graft-versus-host disease. Blood. (2015) 125:606-15. doi: 10.1182/blood-2014-08-551994
68. Vadakekolathu J, Rutella S. T-cell manipulation strategies to prevent graftversus-host disease in haploidentical stem cell transplantation. Biomedicines. (2017). 5:33. doi: 10.3390/biomedicines5020033

69. Penack O, Marchetti M, Ruutu T, Aljurf M, Bacigalupo A, Bonifazi F, et al. Prophylaxis and management of graft versus host disease after stem-cell transplantation for haematological malignancies: updated consensus recommendations of the European Society for Blood and Marrow Transplantation. Lancet Haematol. (2020) 7:e157-67. doi: 10.1016/S2352-3026(19)30256-X

70. van Burik JA, Carter SL, Freifeld AG, High KP, Godder KT, Papanicolaou GA, et al. Higher risk of cytomegalovirus and aspergillus infections in recipients of $\mathrm{T}$ cell-depleted unrelated bone marrow: analysis of infectious complications in patients treated with $\mathrm{T}$ cell depletion versus immunosuppressive therapy to prevent graft-versus-host disease. Biol Blood Marrow Transplant. (2007) 13:1487-98. doi: 10.1016/j.bbmt.2007.08.049

71. Walker CM, van Burik JA, De For TE, Weisdorf DJ. Cytomegalovirus infection after allogeneic transplantation: comparison of cord blood with peripheral blood and marrow graft sources. Biol Blood Marrow Transplant. (2007) 13:1106-15. doi: 10.1016/j.bbmt.2007.06.006

72. Garnett C, Apperley JF, Pavlu J. Treatment and management of graft-versushost disease: improving response and survival. Ther Adv Hematol. (2013) 4:366-78. doi: 10.1177/2040620713489842

73. Stewart BL, Storer B, Storek J, Deeg HJ, Storb R, Hansen JA, et al. Duration of immunosuppressive treatment for chronic graft-versus-host disease. Blood. (2004) 104:3501-6. doi: 10.1182/blood-2004-01-0200

74. Young JA. Infectious complications of acute and chronic GVHD. Best Pract Res Clin Haematol. (2008) 21:343-56. doi: 10.1016/j.beha.2008.02.017

75. Karasuno T. Autologous graft-versus-host disease. Int J Hematol. (1997) 65:105-13. doi: 10.1016/S0925-5710(96)00541-5

76. Mehta RS, Rezvani K. Immune reconstitution post allogeneic transplant and the impact of immune recovery on the risk of infection. Virulence. (2016) 7:901-16. doi: 10.1080/21505594.2016.1208866

77. Elfeky R, Lazareva A, Qasim W, Veys P. Immune reconstitution following hematopoietic stem cell transplantation using different stem cell sources. Expert Rev Clin Immunol. (2019) 15:73551. doi: 10.1080/1744666X.2019.1612746

78. Stern L, McGuire H, Avdic S, Rizzetto S, Fazekas de. St Groth B, Luciani F, et al. Mass cytometry for the assessment of immune reconstitution after hematopoietic stem cell transplantation. Front Immunol. (2018) 9:1672. doi: 10.3389/fimmu.2018.01672

79. Alexandersson A, Koskenvuo M, Tiderman A, Lääperi M, Huttunen P, Saarinen-Pihkala $U$, et al. Viral infections and immune reconstitution interaction after pediatric allogenic hematopoietic stem cell transplantation. Infect Dis (Lond). (2019) 51:772-8. doi: 10.1080/23744235.2019.1650198

80. Hamadani M, Craig M, Awan FT, Devine SM. How we approach patient evaluation for hematopoietic stem cell transplantation. Bone Marrow Transplant. (2010) 45:1259-68. doi: 10.1038/bmt.2010.94

81. Alsuhaibani O, Pereira WC, Tareeqanwar M, Khizzi NE, Bakheswain S, Shaker A, et al. Infectious disease screening among stem cell transplant donors: an institutional experience in Saudi Arabia. Ann Neurosci. (2015) 22:81-6. doi: 10.5214/ans.0972.7531.220206

82. Fries BC, Riddell SR, Kim HW, Corey L, Dahlgren C, Woolfrey A, et al. Cytomegalovirus disease before hematopoietic cell transplantation as a risk for complications after transplantation. Biol Blood Marrow Transplant. (2005) 11:136-48. doi: 10.1016/j.bbmt.2004.11.016

83. Sánchez-Montalvá A, Salvador F, Ruiz-Camps I, Barba P, Valcárcel D, Sulleiro $\mathrm{E}$, et al. Imported disease screening prior to chemotherapy and bone marrow transplantation for oncohematological malignancies. Am J Trop Med Hyg. (2016) 95:1463-8. doi: 10.4269/ajtmh.16-0458

84. Kasow KA, Krueger J, Srivastava DK Li C, Barfield R, Leung W, et al. Clinical utility of computed tomography screening of chest, abdomen, and sinuses before hematopoietic stem cell transplantation: the St. Jude experience. Biol Blood Marrow Transplant. (2009) 15:490-5. doi: 10.1016/j.bbmt.2008.11.033

85. Avivi I, Oren I, Haddad N, Rowe JM, Dann EJ. Stem cell transplantation post invasive fungal infection is a feasible task. Am J Hematol. (2004) 75:6-11. doi: 10.1002/ajh.10447

86. O’Reilly RJ, Koehne G, Hasan AN, Doubrovina E, Prockop S. T-cell depleted allogeneic hematopoietic cell transplants as a platform for adoptive therapy 
with leukemia selective or virus-specific T-cells. Bone Marrow Transplant. (2015) 50(Suppl 2):S43-50. doi: 10.1038/bmt.2015.95

87. Lehrnbecher T, Fisher BT, Phillips B, Beauchemin M, Carlesse F, Castagnola E, et al. Clinical practice guideline for systemic antifungal prophylaxis in pediatric patients with cancer and hematopoietic stem-cell transplantation recipients. J Clin Oncol. (2020) 38:3205-16. doi: 10.1200/JCO.20.00158

88. Penack O, Tridello G, Hoek J, Socié G, Blaise D, Passweg J, et al. Influence of pre-existing invasive aspergillosis on allo-HSCT outcome: a retrospective EBMT analysis by the infectious diseases and acute leukemia working parties. Bone Marrow Transplant. (2016) 51:418-23. doi: 10.1038/bmt.2015.237

89. Fukuda T, Boeckh M, Guthrie KA, Mattson DK, Owens S, Wald A, et al. Invasive aspergillosis before allogeneic hematopoietic stem cell transplantation: 10-year experience at a single transplant center. Biol Blood Marrow Transplant. (2004) 10:494-503. doi: 10.1016/j.bbmt.2004.02.006

90. Annaloro C, Serpenti F, Saporiti G, Galassi G, Cavallaro F, Grifoni F, et al. Viral infections in HSCT: detection, monitoring, clinical management, and immunologic implications. Front Immunol. (2020) 11:569381. doi: 10.3389/fimmu.2020.569381

91. Düver F, Weißbrich B, Eyrich M, Wölfl M, Schlegel PG, Wiegering V. Viral reactivations following hematopoietic stem cell transplantation in pediatric patients - a single center 11-year analysis. PLoS ONE. (2020) 15:e0228451. doi: 10.1371/journal.pone.0228451

92. Freifeld AG, Bow EJ, Sepkowitz KA, Boeckh MJ, Ito JI, Mullen CA, et al. Clinical practice guideline for the use of antimicrobial agents in neutropenic patients with cancer: 2010 update by the infectious diseases society of america. Clin Infect Dis. (2011) 52:e56-93. doi: 10.1093/cid/cir073

93. van Burik JA, Ratanatharathorn V, Stepan DE, Miller CB, Lipton JH, Vesole DH, et al. Micafungin versus fluconazole for prophylaxis against invasive fungal infections during neutropenia in patients undergoing hematopoietic stem cell transplantation. Clin Infect Dis. (2004) 39:140716. doi: $10.1086 / 422312$

94. Pollack M, Heugel J, Xie H, Leisenring W, Storek J, Young JA, et al. An international comparison of current strategies to prevent herpesvirus and fungal infections in hematopoietic cell transplant recipients. Biol Blood Marrow Transplant. (2011) 17:664-73. doi: 10.1016/j.bbmt.2010.07.026

95. MacMillan ML, Goodman JL, DeFor TE, Weisdorf DJ. Fluconazole to prevent yeast infections in bone marrow transplantation patients: a randomized trial of high versus reduced dose, and determination of the value of maintenance therapy. Am J Med. (2002) 112:36979. doi: 10.1016/S0002-9343(01)01127-5

96. van Burik JA. Role of new antifungal agents in prophylaxis of mycoses in high risk patients. Curr Opin Infect Dis. (2005) 18:479-83. doi: 10.1097/01.qco.0000185984.57135.ad

97. Cronin S, Chandrasekar PH. Safety of triazole antifungal drugs in patients with cancer. I Antimicrob Chemother. (2010) 65:410-6. doi: 10.1093/jac/dkp464

98. Cornely OA, Pappas PG, Young JA, Maddison P, Ullmann AJ. Accumulated safety data of micafungin in therapy and prophylaxis in fungal diseases. Expert Opin Drug Saf. (2011) 10:171-83. doi: 10.1517/14740338.2011.557062

99. Chen K, Cheng MP, Hammond SP, Einsele H, Marty FM. Antiviral prophylaxis for cytomegalovirus infection in allogeneic hematopoietic cell transplantation. Blood Adv. (2018) 2:215975. doi: 10.1182/bloodadvances. 2018016493

100. Shigle TL, Handy VW, Chemaly RF. Letermovir and its role in the prevention of cytomegalovirus infection in seropositive patients receiving an allogeneic hematopoietic cell transplant. Ther Adv Hematol. (2020) 11:2040620720937150. doi: 10.1177/2040620720937150

101. Redjoul R, Robin C, Foulet F, Leclerc M, Beckerich F, Cabanne L, et al. Pneumocystis jirovecii pneumonia prophylaxis in allogeneic hematopoietic cell transplant recipients: can we always follow the guidelines? Bone Marrow Transplant. (2019) 54:1082-8. doi: 10.1038/s41409-018-0391-2

102. Horton LE, Haste NM, Taplitz RA. Rethinking antimicrobial prophylaxis in the transplant patient in the world of emerging resistant organisms-where are we today? Curr Hematol Malig Rep. (2018) 13:59-67. doi: 10.1007/s11899-018-0435-0

103. Khoruts A, Hippen KL, Lemire AM, Holtan SG, Knights D, Young JH. Toward revision of antimicrobial therapies in hematopoietic stem cell transplantation: target the pathogens, but protect the indigenous microbiota. Transl Res. (2017) 179:116-25. doi: 10.1016/j.trsl.2016.07.013

104. Taur Y, Jenq RR, Perales MA, Littmann ER, Morjaria S, Ling L, et al. The effects of intestinal tract bacterial diversity on mortality following allogeneic hematopoietic stem cell transplantation. Blood. (2014) 124:117482. doi: 10.1182/blood-2014-02-554725

105. Zama D, Biagi E, Masetti R, Gasperini P, Prete A, Candela M, et al. Gut microbiota and hematopoietic stem cell transplantation: where do we stand? Bone Marrow Transplant. (2017) 52:7-14. doi: 10.1038/bmt.2016.173

106. Rashidi A, Ebadi M, Shields-Cutler RR, DeFor TE, Al-Ghalith GA, Ferrieri P, et al. Pretransplant gut colonization with intrinsically vancomycin-resistant Enterococci (E. gallinarum and E. casseliflavus) and outcomes of allogeneic hematopoietic cell transplantation. Biol Blood Marrow Transplant. (2018) 24:1260-3. doi: 10.1016/j.bbmt.2018.01.025

107. Papanicolaou GA, Ustun C, Young JH, Chen M, Kim S, Woo Ahn K, et al. Bloodstream infection due to vancomycin-resistant enterococcus is associated with increased mortality after hematopoietic cell transplantation for acute leukemia and myelodysplastic syndrome: a multicenter, retrospective cohort study. Clin Infect Dis. (2019) 69:1771-9. doi: 10.1093/cid/ciz031

108. Benamu E, Deresinski S. Vancomycin-resistant enterococcus infection in the hematopoietic stem cell transplant recipient: an overview of epidemiology, management, and prevention. F1000Res. (2018). 7:3. doi: 10.12688/f1000research.11831.1

109. Singhal S, Mehta J. Reimmunization after blood or marrow stem cell transplantation. Bone Marrow Transplant. (1999) 23:637-46. doi: 10.1038/sj.bmt.1701640

110. Tsang V. Vaccination recommendations for the hematology and oncology and post-stem cell transplant populations. J Adv Pract Oncol. (2012) 3:7183. doi: 10.6004/jadpro.2012.3.2.2

111. Pollyea DA, Brown JM, Horning SJ. Utility of influenza vaccination for oncology patients. J Clin Oncol. (2010) 28:248190. doi: 10.1200/JCO.2009.26.6908

112. Pao M, Papadopoulos EB, Chou J, Glenn H, Castro-Malaspina H, Jakubowski $\mathrm{AA}$, et al. Response to pneumococcal (PNCRM7) and Haemophilus influenzae conjugate vaccines (HIB) in pediatric and adult recipients of an allogeneic hematopoietic cell transplantation (alloHCT). Biol Blood Marrow Transplant. (2008) 14:1022-30. doi: 10.1016/j.bbmt.2008.06.012

113. Pergam SA, Englund JA, Kamboj M, Gans HA, Young JH, Hill JA, et al. Preventing measles in immunosuppressed cancer and hematopoietic cell transplantation patients: a position statement by the American society for transplantation and cellular therapy. Biol Blood Marrow Transplant. (2019) 25:e321-30. doi: 10.1016/j.bbmt.2019.07.034

114. Rubin LG, Levin MJ, Ljungman P, Davies EG, Avery R, Tomblyn $\mathrm{M}$, et al. (2013). IDSA clinical practice guideline for vaccination of the immunocompromised host. Clin Infect Dis. (2014) 58:30918. doi: $10.1093 / \mathrm{cid} / \mathrm{cit} 816$

115. Hilgendorf I, Freund M, Jilg W, Einsele H, Gea-Banacloche J, Greinix $\mathrm{H}$, et al. Vaccination of allogeneic haematopoietic stem cell transplant recipients: report from the international consensus conference on clinical practice in chronic GVHD. Vaccine. (2011) 29:2825-33. doi: 10.1016/j.vaccine.2011.02.018

116. Carpenter PA, Englund JA. How I vaccinate blood and marrow transplant recipients. Blood. (2016) 127:2824-32. doi: 10.1182/blood-2015-12-550475

117. Bacigalupo A. How I treat acquired aplastic anemia. Blood. (2017) 129:142836. doi: 10.1182/blood-2016-08-693481

118. Zama D, Bossù G, Leardini D, Muratore E, Biagi E, Prete $\mathrm{A}$, et al. Insights into the role of intestinal microbiota in hematopoietic stem-cell transplantation. Ther Adv Hematol. (2020) 11:2040620719896961. doi: 10.1177/2040620719896961

119. Vaughan D, Pakyz A, Stevens M, Lee K, Bernard S. Adequacy of empiric gram-negative coverage for septic patients at an academic medical center. Am J Infect Control. (2019) 47:1194-9. doi: 10.1016/j.ajic.2019.03.037

120. Bhanushali MJ, Kranick SM, Freeman AF, Cuellar-Rodriguez JM, Battiwalla M, Gea-Banacloche JC, et al. Human herpes 6 virus encephalitis complicating allogeneic hematopoietic stem cell transplantation. Neurology. (2013) 80:1494-500. doi: 10.1212/WNL.0b013e31828cf8a2 
121. Kasberg-Koniarczyk HL. Human Herpesvirus-6 encephalitis after hematopoietic stem cell transplantation. J Adv Pract Oncol. (2014) 5:373-8. doi: 10.6004/jadpro.2014.5.5.8

122. El Jurdi N, Rogosheske J, DeFor T, Bejanyan N, Arora M, Bachanova V, et al. Prophylactic foscarnet for human Herpesvirus 6: effect on hematopoietic engraftment after reduced-intensity conditioning umbilical cord blood transplantation. Biol Blood Marrow Transplant. (2020). doi: 10.1016/j.bbmt.2020.10.008

123. De Bolle L, Naesens L, De Clercq E. Update on human herpesvirus 6 biology, clinical features, and therapy. Clin Microbiol Rev. (2005) 18:21745. doi: 10.1128/CMR.18.1.217-245.2005

124. Silva RM, Bazzo ML, Borges AA. Induced sputum versus bronchoalveolar lavage in the diagnosis of pneumocystis jiroveci pneumonia in human immunodeficiency virus-positive patients. Braz J Infect Dis. (2007) 11:54953. doi: 10.1590/S1413-86702007000600005

125. An SH, Wang MM Li JY, Zheng BJ, Wang YY, Zhao QJ, et al. [Role of flexible bronchoscopy in the diagnosis and treatment of refractory pneumonia in children]. Zhongguo Dang Dai Er Ke Za Zhi. (2011) 13:547-50.

126. Davies BI. Critical review of microbiological data and methods in diagnosis of lower respiratory tract infections. Monaldi Arch Chest Dis. (1994) 49:52-6.

127. Held TK, Krüger D, Switala AR, Beyer J, Kingreen D, Busemann C, et al. Diagnosis of toxoplasmosis in bone marrow transplant recipients: comparison of PCR-based results and immunohistochemistry. Bone Marrow Transplant. (2000) 25:1257-62. doi: 10.1038/sj.bmt.17 02457

128. Steele RW. Should immunocompromised patients have pets? Ochsner J. (2008) 8:134-9.
129. Kalivas PW. Histamine-induced arousal in the conscious and pentobarbitalpretreated rat. J Pharmacol Exp Ther. (1982) 222:37-42.

130. Hemsworth S, Pizer B. Pet ownership in immunocompromised children-a review of the literature and survey of existing guidelines. Eur J Oncol Nurs. (2006) 10:117-27. doi: 10.1016/j.ejon.2005.08.001

131. Bock AM, Cao Q, Ferrieri P, Young JA, Weisdorf DJ. Bacteremia in blood or marrow transplantation patients: clinical risk factors for infection and emerging antibiotic resistance. Biol Blood Marrow Transplant. (2013) 19:102-8. doi: 10.1016/j.bbmt.2012.08.016

Conflict of Interest: The authors declare that the research was conducted in the absence of any commercial or financial relationships that could be construed as a potential conflict of interest.

Publisher's Note: All claims expressed in this article are solely those of the authors and do not necessarily represent those of their affiliated organizations, or those of the publisher, the editors and the reviewers. Any product that may be evaluated in this article, or claim that may be made by its manufacturer, is not guaranteed or endorsed by the publisher.

Copyright (๑) 2021 Ferdjallah, Young and MacMillan. This is an open-access article distributed under the terms of the Creative Commons Attribution License (CC BY). The use, distribution or reproduction in other forums is permitted, provided the original author(s) and the copyright owner(s) are credited and that the original publication in this journal is cited, in accordance with accepted academic practice. No use, distribution or reproduction is permitted which does not comply with these terms. 